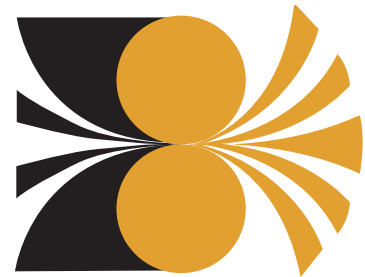

GOLD 2003

NEW INDUSTRIAL USES FOR GOLD
Gold 2003 Vancouver, Canada

28 September - 1 October 2003

\title{
International
}

\section{Conference Update}

\section{Patrons}

Prof Ceoffrey Bond, University of Salford, UK

Dr Masatake Haruta, Research Institute for Green

Technology, AIST, Japan

Prof Hubert Schmidbaur, Technical University of

Munich, Germany

\section{SECOND CIRCULAR}

The second circular is now available, giving full programme details. To obtain a copy, please contact the Conference Secretariat at the address on page 64 .

\section{ORIENTATION WORKSHOPS}

Keynote talks will be:

Professor Graham Hutchings, Cardiff UK, 'New Direction in Gold Catalysis'

Professor Hubert Schmidbaur, Munich, Germany,

'Fundamental Knowledge in Gold Chemistry: Sound Basis for Multidisciplinary Development'

Professor Michael Cortie, Sydney, Australia, 'The Weird World of Nanoscale'

Dr Christopher Corti \& Dr Richard Holliday, 'Commercial

Aspects of Gold Applications': from Materials Science to

Chemical Science.

\section{From the Conference Chairman:}

Gold 2003 promises to be an exciting conference for a number of reasons. The organising committee have been pleasantly surprised at the number and quality of abstracts submitted. This confirms that the gold R \& D community needs a dedicated forum to discuss the latest advances in gold science and technology. We have consequently decided to run 4 parallel sessions at the conference in order to ensure that over 140 papers and posters can be presented and discussed.

It also suggests that there is a lot of innovative research into gold science and technology being undertaken in universities and industrial research laboratories around the world; a fact that, perhaps, needs publicising! Gold may be the oldest metal known and utilised by man, but it is also a 21st century metal, suited to modern needs. We do need to ensure that this new emerging science is brought to the attention of industry in order to encourage its commercial exploitation to the benefit of mankind. That is one of the principal aims of this conference and we encourage both researchers and industrialists to participate.

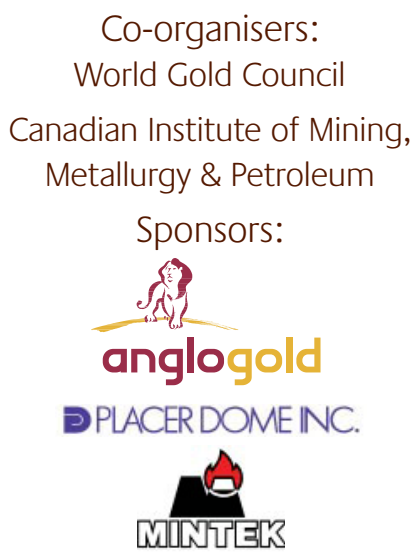

PLENARY KEYNOTES

Keynote talks confirmed to date include:

1. Dr Masatake Haruta, Tsukuba, Japan, 'Cold as a Novel Catalyst in the 21st Century: Preparation, Working Mechanism and Applications'

2. Professor Hajo Freund, Berlin, Germany, 'Surface Chemistry of Catalysis by Gold'

3. Professor Stephen Hashmi, Stuttgart, Germany, 'Homogeneous Catalysis by Gold'

4. Professor Declan Burke, Cork, Ireland, 'Scope for New Applications for Gold Arising from the Electrocatalytic Behaviour of its Metastable Surface States'

5. Professor Pekka Pyykko, Helsinki, Finland, 'Cold, Relativity and Nanosized Systems'

6. Professor Alan Balch, University of California, USA, 'Luminescence from Gold Complexes'

7. Dr Yutaka Okinaka, Waseda, Japan and Dr. Masaru Kato Kanto Chemical Co., 'Some Recent Developments in Non-Cyanide Gold Plating'

8. Dr Tim Ellis, Kulicke and Soffa Industries, USA, The Future of Gold in Electronics'

9. Professor Naomi Halas, Houston, USA, 'The Remarkable Optical Properties of Gold Nanoshells'

10. Dr Bruce Cornell, Ambri Ltd, Australia, 'Novel Time Diagnostic Device Based on a Biomimetric Membrane Tethered to a Gold Surface'

11. Professor Kunio Takayanagi, Japan, "Helical gold nanowire"

Gold catalysis is a major new emerging science, and we pioneered the first conference 2 years ago under the title "Catalytic Gold" in Cape Town. This title will live on at Gold 2003 where over 55 oral presentations demonstrate the huge interest in this field. The potential applications are wide-ranging, as we see from many patents being obtained, and industrialists cannot afford to ignore this rich opportunity to tap into the latest technology.

There are exciting developments in gold chemistry, nanotechnology and materials too which also offer unique opportunities for commercial exploitation. I am convinced that this conference will be an amazing success for researchers and industrialists alike. You must be there, if you do not want to miss out!

I look forward to welcoming you all at Vancouver!

Dr Christopher W. Corti

Chairman, Gold 2003 Organising Committee 


\section{Programme Update and Session Titles}

At this stage, it is envisaged that there will be four parallel sessions to the conference. These will embrace the four topic areas within a multidisciplinary approach: Catalysis (under the title 'Catalytic Gold', used at the Cape Town conference), Chemistry, Materials and Nanotechnology.

In addition to the

presentations, a poster session, an Open Forum discussion on specific

\section{CATALYSIS:}

Fundamentals in Gold Catalysis:

Hydrogen Processing and Fuel Cell Applications

Surface Chemistry and Catalysis

Applications for Gold Catalysts

New Routes to Chemicals via Homogeneous Catalysis

Advances in Heterogeneous Catalysis

Bimetallic Catalysts

Gold Catalysts in Chemical Processing

Catalyst Preparation and Characterisation

Electro- and Nano-Catalysts

New Catalysts

\section{CHEMISTRY:}

Theoretical Chemistry and Reaction Mechanisms

Electrochemistry and Gold Extraction

New Gold Chemistry

Please send me full programme and registration information I am interested in the following session(s) - tick all those that apply

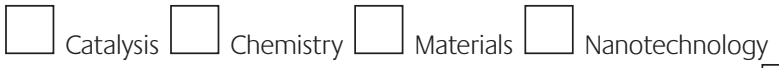

I intend to submit an abstract for poster presentation

I intend to participate as a delegate only

My spouse/partner is likely to attend with me

Title _ First name

Last name

Position

Organisation

Address

City

Postal/zip code Country

Tel

Fax

Email

\section{Send to:}

Gold 2003 Conference Secretariat

Canadian Institute of Mining Metallurgy and Petroleum

3400 de Maisonneuve Blvd West Suite 1210

Montreal

Quebec

Canada

H3Z 3B8

Fax: +1 5149395587

Email: smajor@cim.org gold science and technology. be published on the conference website, www.gold2003.org in due course.

\section{Student posters}

In order to encourage students, particularly those currently undertaking gold research, it is planned to keep offers of abstracts for posters open until August
2003, so that those students who would like to present their 'latest results' are encouraged to present and benefit from interaction with other attendees. Such abstracts for posters may continue to be submitted via the conference website.

Details of special student rates and accommodation are posted on the website.
Photoluminescent Compounds for Optronics Pharmaceutical Applications

\section{MATERIALS:}

Innovations in Electroplating

Gold in Medical and Dental Applications

New Electronic Materials

Advanced Gold Alloys

\section{NANOTECHNOLOGY:}

Future Horizons in Nano-tech

Nano-particle Composites

Nanotechnology Applications

Manufacture of Nano-particles

\section{Venue}

Vancouver is the venue for the Gold 2003 conference. The Conference hotel is the Westin Bayshore Resort and Marina, Vancouver, nestled on the shores of Coal Harbour and overlooking the third largest city park in North America the 1,000 acre Stanley Park - with the breathtaking Coastal Mountains beyond. This excellent location provides direct access to Vancouver's most popular business, shopping and entertainment districts. This award winning hotel and new Conference Centre offers superb facilities for an international conference and provides for excellent accommodation.

\section{Website}

Full information on the conference can be found on the conference website at www.gold2003.org

\section{Proceedings}

Proceedings will be published as a separate CD-Rom, included within the conference fee.

\section{Students}

Special student rates for conference attendance are announced on the website.

\section{Registration}

Full registration information, including conference fees and hotel accommodation, is on the conference website, www.gold2003.org. Details of accompanying persons tours are also be listed.

Early registration before 31st July will attract discount registration fee.

Questions regarding the conference technical programme should be addressed to:

Technical Programme Co-ordinator, Gold 2003

International Technology, World Gold Council

45 Pall Mall, London SW1Y 5JG UK.

Fax: $\quad$ +44207839 6561

Email: gold2003@gold.org 